\title{
PENALTY CLAUSES IN ENGLAND AND FRANCE: A COMPARATIVE STUDY
}

\author{
LUCINDA MILLER
}

The study of penalty clauses ${ }^{1}$ is a rewarding area of comparative research. The most cursory of examinations reveals the diametrically opposed theoretical positions of contemporary legal orthodoxy in France and England. A search for the rationale behind this theoretical divergence gives insight not only into the broader conceptual and substantive differences between the two jurisdictions, but, importantly, their many similarities as well.

The law on penalty clauses is an excellent illustration of the tension found throughout contract law which is common to most systems and to all periods of contractual history - the conflict between freedom of contract, individual justice and legal (and thus commercial) certainty. The dynamic nature of the rules and their continuing legal metamorphosis reflect the prevailing philosophical, economic and legal theories of the time. ${ }^{2}$ The gradual decline of the 'Will Theory' from its once privileged doctrinal position and the subsequent erosion of absolute principles of freedom of contract has lent greater legitimacy to judicial intervention that secures protection for the individual. It has also encouraged the courts to resurrect and develop equitable principles from the nineteenth century. ${ }^{3}$ In the realm of penalty clauses this means greater judicial vigilance over repressive terms (or, perhaps more accurately, greater

* LL B, LL M, Doctoral Candidate and Tutor at University College London. I am extremely grateful to Professor Michael Bridge for his invaluable comments during discussions and his remarks on an earlier draft. I would also like to acknowledge the support received from the Arts and Humanities Research Board.

1 The term is problematic in a comparative study. In England it specifically refers to an invalid agreed damages clause. A valid clause is referred to as a liquidated damages clause. In France, the term clause pénale encapsulates both English notions. Unless obvious from the context, the term 'penalty clauses' will connote both valid and invalid agreed damages clauses as well as the French clause pénale.

2 One French author considers the penalty clause rules a precursor for general contractual developments representing 'une image assez exacte des modifications qui ont affecté le droit contractuel'. D Mazeaud, La Notion de Clause Pénale (LGDJ 1992) at 31. It is a comment equally valid in England.

3 See D Ibbetson An Historical Introduction to the Law of Obligations (Oxford Oxford University Press 1999) 249 who outlines how the incursion into the Will Theory from competing socio-economic, philosophical and legal theories created a suitable climate for more active judicial control of unconscionable behaviour of contracting parties. Whilst at first this did not amount to a wholesale renouncement of the Will Theory, it was recognition that contracts could be more extensively regulated by principles of reasonableness and justice. By the later part of the twentieth century, the Will Theory had been 'seriously compromised' (at 261). 
vigilance over a repressive imbalance in bargaining power). ${ }^{4}$ Loss of legal certainty however, proves to be the price of intervention. The extent to which certainty can be sacrificed and terms of a contract 'rewritten' will fluctuate according to the dominant legal and socio-economic values of the time. In contemporary times, these values are sourced from beyond national boundaries to embrace the market integrative goals of the European Community. The 'disruptive' influence of European-wide norms on the evolutionary journey of the penalty clause rules epitomises the more general impact of the EC integrationist project on the private law systems of Member States. More specifically, the future of the penalty clause will no longer be a purely national concern.

\section{THE DEVELOPMENT OF THE PENALTY CLAUSE RULES}

\section{A. English Agreed Damages Clauses}

In England, a payment clause is enforceable when it functions as a liquidated damages clause but 'disregarded' 5 where it is held to be a penalty clause. The former represents a genuine pre-estimate of damages, whether actual (or recoverable) loss amounts to more or less than the sum stipulated; the latter is stipulated as in terrorem of the offending party. This prohibition of the penalty clause $^{6}$ accords with the English conception of damages. Since the purpose of an award of damages is to compensate the claimant, ${ }^{7}$ it follows that it would be illegitimate to allow a clause in a contract that stipulated for a sum which is in excess of the actual loss of the obligee. As Lord Roskill states

Perhaps the main purpose of the law relating to penalty clauses is to prevent a plaintiff recovering a sum of money in respect of a breach of contract committed by a defendant which bears little or no relationship to the loss actually suffered by the plaintiff as a result of the breach by the defendant. ${ }^{8}$

When classifying the clause the court will take into account the intention of the parties as to its purpose, ${ }^{9}$-in other words whether it is genuinely to calculate

\footnotetext{
4 It will be seen below that in England, unlike in France, even at the height of the enlightenment, penalty clauses were treated with suspicion. Intervention however was restrained by strict delimitation of what was classified as a penalty clause. A clause was only treated as penal if it could not have represented the parties' intentions. See Ibbetson, op cit at 255.

5 This, at least, is the traditional language used. The significance of the term is explored below.

6 It should be noted that the common law has not always been distrustful of penalties. The penal bond with conditional defeasance was a much used instrument until the mid-seventeenth century. A full account can be found in AWB Simpson 'The Penal Bond with Conditional Defeasance' [1966] 92 LQR 392.

7 Tai Hing cotton Mill v Kamsing Knitting Factory [1979] AC 95, at 105.

8 Export Credits Guarantee Department v Universal Oil Products [1983] 2 Lloyd's Rep 152, at 155 .

9 ' $[\mathrm{T}]$ he distinction between penalties and liquidated damages depends on the intention of the parties to be gathered from the whole of the contract' Law v Redditch Local Board [1892] 1 QB 127 , at 132 .
} 
loss in advance or to punish, or to deter, breach. But the denomination given to the clause by the parties is indicative, as opposed to determinative. ${ }^{10}$ Classification is a question of construction to be determined by the court, taking into consideration the terms and particular circumstances of the contract at the time it was concluded, not at the time of breach. ${ }^{11}$

Certain principles will assist the court in its classification. These were set out in Dunlop Pneumatic Tyre Co Ltd v New Garage \& Motor Co Ltd ${ }^{12}$ in a four-part test: ${ }^{13}$

1. The clause will be classified as a penalty clause where the sum stipulated is 'extravagant and unconscionable in amount in comparison with the greatest loss that could conceivably be proved to have followed from the breach'. The less the parties attempt to proportion the loss to likely damages, the less probable it is that the clause will be upheld. ${ }^{14}$

2. Where the breach only consists in not paying a sum of money and the sum stipulated is a sum greater than the sum which ought to have been paid, then again the clause will be classified as penal. In principle, this rule will apply even where the agreement is between parties of equal bargaining strength and would be considered a fair apportionment of risk. But the courts do seem reluctant to apply the rule strictly, ${ }^{15}$ a good example being Wallis $v$ Smith $^{16}$ where a clause was narrowly construed to avoid it being applicable to the obligor's breach and consequently falling within this second rule. Controversially it will be seen (in Part III) that the rule does not apply in the case of an acceleration clause and can be further circumvented by stipulating a high contract price with a discount for early payment. The utility of the rule has been seriously questioned ${ }^{17}$ and the criticism gains particular force when remembering that the financial losses arising consequentially from non-payment can be substantial and often difficult to calculate. Maintaining the rule offers little practical advantage since, faced with an unconscionable sum, the courts could always turn to the first rule.

3. Where a single lump sum is to be payable on the occurrence of one, or more, or all of several breaches, some of which may occasion serious and others trifling damage, then there is a presumption that the clause is a penalty. This does not mean that the breach that actually occurs must be a trifling one. It is enough that actual loss might be far less than the

10 See, eg, Kemble v Farren (1829) 6 Bing 141 where a clause described as a 'liquidated damages clause' was held to be a penalty clause and, for the reverse, see Elphinstone v Monkland Iron \& Coal Co Ltd (1886) 11 App Cas 332.

11 Dunlop Pneumatic Tyre Co Ltd v New Garage \& Motor Co Ltd [1915] AC 79, at 87.

12 Above $\mathrm{n} 11$.

13 At $87-8$

14 Butterworths Common Law Series The Law of Contracts (London Butterworths 1999) 1303.

15 G Treitel The Law of Contract (London Sweet \& Maxwell 1999) 930.

16 (1882) 21 Ch D 243.

17 See Treitel above n 15, at 931; Butterworths, above n 14, at 1304. 
penalty sum. As Treitel states ${ }^{18}$ this could result in the courts invalidating perfectly fair bargains because of improbable and extraordinary events that have not in fact occurred. The rule also largely depends on how the range of possibilities ex ante is assessed. The more modern approach of Lord Woolf, discouraging arguments based on 'unlikely illustrations', ${ }^{19}$ suggests that the courts will not be receptive to this rule where the clause is a fair and reasonable one agreed between parties of equal bargaining strength.

4. But there is nothing to prevent the sum representing a liquidated damages clause where the consequences of breach are such that a 'precise pre-estimation' is impossible. In fact, where exact calculation is impossible, it is quite likely that 'pre-estimated damage was the true bargain between the parties' ${ }^{20}$ Even under this fourth rule however, if the sum stipulated is extravagant or unconscionable it will be considered penal.

The legal bifurcation of agreed damages clause, resulting in a separation between liquidated damages and penalty clauses, rests on the assumption that they have an unequivocally divisible nature. In other words, it presupposes that they are either one thing or the other. But this analysis is problematic. Even where one 'function' of the clause overshadows the other it is not always the case that the other 'function' will be completely eliminated. Where the intention of the parties is not clear, or where their intention is twofold, (to include both a coercive and compensatory element to the clause), then predicating the legitimacy of judicial control on the parties having a singular purpose will be artificial. $^{21}$

There is a further theoretical difficulty that flows from a division of the clauses that is premised on their repressive (or not) nature. Penalties 'may quite readily be undertaken by parties who are not in the least terrorised by the prospect of having to pay them'. ${ }^{22}$ Conversely, a clause considered a genuine pre-estimate of loss may have a highly coercive effect on the obligor, fearful of paying the damages agreed. Classification therefore can be misleading.

A different problem arises where either a change in circumstances between the time of conclusion and breach or, in accordance with technical application of the third and fourth rules, what may have been stipulated in terrorem results in a 'penalty' inferior to loss suffered. ${ }^{23}$ This paradoxical situation offers two possible solutions; either the 'penalty' could be 'disregarded' allowing the

\footnotetext{
18 Above n 15, at 93.

19 Philips Hong Kong v A-G of Hong Kong (1993) 61 Build LR 41, at 59.

20 Dunlop, at 88 . This seems in contradiction with the third rule.

21 The difficulty with the common law distinction is evidenced in the contradictory cases of Dunlop and Ford Motor Co v Armstrong (1915) 31 TLR267.

22 Bridge v Campbell Discount Co Ltd [1962] AC 600, at 622.

23 See on this Barton 'Penalties and Damages' [1976] 92 LQR 26; Gordon [1974] 90 LQR 296; Hudson 'Penalties Limiting Damages' [1974] 90 LQR 30.
} 
obligee to claim damages for actual loss, or it will act as a limit on the amount of damages recoverable. The justification for the latter stance is that if the invalidity of a penalty is predicated on its coercive nature then a sum that works in an obligor's favour cannot be considered as oppressive. The first solution aligns better with the rule that the purpose of the clause must be assessed at the time of conclusion of the contract. The resulting loss suffered should be irrelevant to the classification process. It was a view given judicial recognition in Wall $\mathrm{v}$ Rederiaktiebolaget Lugudde $;^{24}$ the obligee was able to disregard the penalty and recover his actual loss. But in the later Cellulose Acetate ${ }^{25}$ case Lord Atkin stated that he 'wished to leave open the question' whether to ignore or uphold the clause. Nor was the issue conclusively settled in Robophone,${ }^{26}$ Lord Justice Diplock choosing only to express doubt as to whether a penalty clause would always be 'void' (in his Lordship's words) in such situations.

A Canadian Supreme Court decision supports the second of the solutions suggested. ${ }^{27}$ It was held that the party who imposes the penalty should not be able to benefit from the repressive nature of the penal element in the clause and then be able to ignore the clause when it suits him to do so. The penalty clause should thus function as a limitation on recoverable damages - it should be the maximum amount recoverable, whilst also being ineffective to increase damages above actual loss sustained if loss is less than the stipulated amount. The rationale for this principle draws on the underlying purpose of the penalty clause rules - since they provide relief against oppression, in the absence of such oppression they should not apply. ${ }^{28}$

This view avoids the pitfalls of the Luggude principle where a person infringing the law might be in a better position than a person conforming to it - a sum considered a valid liquidated damages clause will be upheld even where loss is more; an invalid, (illegal) penalty will be disregarded and the party will be able to recover his actual loss. ${ }^{29}$ On the other hand however, allowing a penalty clause to operate where actual loss is greater, but denying its application where loss is less, is arguably penal vis-à-vis the obligee. This is particularly true when one remembers that in circumstances of equal bargaining power the obligee may have paid a high price for the 'imposition' of the penalty.

24 [1915] 3 K B 66

25 Cellulose Acetate Silk Co Ltd v Widnes Foundry (1925) Ltd. [1933] AC 20.

26 Robophone Facilities Ltd v Blank [1966] 3 All ER129, at 142.

27 Elsley v JG Collins Ins Agencies Ltd (1978) 83 DLR (3d) 1.

${ }^{28}$ Perhaps a simplified way of looking at this would be to ask whether the same clause can be recognised as pursuing multifarious purposes; eg coercion, compensation and limitation. If so, a refusal to enforce a penalty clause could be viewed as ignoring one characteristic of the particular clause (viz coercion) whilst leaving another (viz limitation) to be enforced. The traditional common law separation of a penalty from a liquidated damages clause tends to hinder this process of analysis since it presupposes that the clause has either one function or another. Jobson $v$ Johnson [1989] 1 WLR 1026 (discussed in detail below) represents a move towards viewing the same clause as having an amalgam of functions.

${ }^{29}$ See Hudson, above $\mathrm{n} 23$. 
This leads to an important point. The solution suggested in Luggude (and intimated as the correct one by most writers) is inconsistent with the Court of Appeal decision of Jobson $v$ Johnson $^{30}$ which concerns the fate of the clause once classified as penal. Academic and judicial commentary has not highlighted this point in the way that its importance perhaps warrants. The penalty clause is simply said to be either 'wholly disregarded', 31 'invalid',32 'unenforceable', 33 or 'replaced' 34 with a sum of money that represents compensation for loss, with little discussion on what these terms actually entail. ${ }^{35}$ According to Jobson $v$ Johnson however, the strict legal position is that the clause is not simply struck out of the contract 'as though with a blue pencil' ${ }^{36}$ Instead, it 'remains in the contract and can be sued on, but it will not be enforced by the court beyond the sum which represents the actual loss of the party seeking payment ... ${ }^{37}$ In other words, it will be enforced to the extent that it does not function as a penalty. Where actual loss is less, then the clause will be 'scaled down' 38 by the court.

The legal consequences are important. The obligee is able to sue on the penalty clause, so far as it is not penal, ${ }^{39}$ rather than, where the clause is 'disregarded,' or struck out, simply having an action for unliquidated damages. Although Nicholls LJ considered that there is "normally' 40 no practical advantage in suing on the penalty clause, ${ }^{41}$ since under it the obligee is unable to recover more than proved damages, in fact, the obligee would not have any of the problems with quantification, mitigation or remoteness that arise in the case of an action for damages. ${ }^{42}$ This might suggest that the obligee would be encouraged to insert a penalty clause in order to circumvent the normal problems of a claim in damages. But, according to Jobson $v$ Johnson, ${ }^{43}$ where loss

\footnotetext{
30 Above $\mathrm{n} 28$

31 R Zimmermann The Law of Obligations. Roman Foundations of the Civilian Traditions (Cape Town Juta \& Co 1990), at 107.

32 Treitel, above $\mathrm{n} 15$, at 929.

33 E Mckendrick Contract Law (London Palgrave 2000), at 430; Butterworths, above n 14, at 1295; and Clarkson et al 'Liquidated Damages $v$ Penalties: Sense or Nonsense' [1978] Wisc LR 351 , at 351 .

34 H Collins The Law of Contract (London Butterworths 1997), at 347.

35 Harris 'Incentives to Perform or Break Contracts' (1992) 45 CLP 29, at 37 and Downes, 'Rethinking Penalty Clauses' in Birks (ed) Wrongs and Remedies in the Twenty-First Century (Oxford Clarendon Press 1996), at 153, are noteworthy exceptions.

36 Above n 28, at 1030. This can be compared with, eg, an 'unreasonable' exclusion clause which seeks to exclude or restrict liability for breach of contract under UCTA 1977, or a provision imposing unlawful restraints on trade.

37 Above n 28, at 1040 .

38 Above $\mathrm{n} 28$, at 1042 .

39 There is an action in debt for the recoverable part of the penalty clause.

40 Above $n$ 28, at 1040 .

41 And thus it has become a 'dead letter' (at 1039).

42 White and Carter (Councils) Ltd v McGregor [1962] AC 413 shows the advantages of a claim in debt. The claimants were not obliged to mitigate their loss. The advantages in avoiding the remoteness rules are exemplified in Robophone Facilities Ltd v Blank above n 26.

43 And Elsley v JG Collins Ins Agencies Ltd, above n 27.
} 
is more than the penalty clause, the clause will act as a limitation on recoverable damages - a claim in debt means neither more, nor less, can be recovered.

The ramifications of Jobson $v$ Johnson also extend to the comparative level. By 'scaling-down' the clause and enforcing it to the extent that it does not function as a penalty (rather than 'wholly disregarding' it and striking it from the contract) the court is, in essence, 'modifying' the clause. This modification exercise is evocative of the rules relating to the clause pénale in France following the 1975 reform. Whilst it will be seen that the penal element of the clause is not entirely suppressed in France, Jobson v Johnson nevertheless could be viewed as confirming a subtle convergence of approach between the two systems. The extent to which both jurisdictions accord with EC legislation in the consumer area will be examined in Section V.

\section{$B$. La Clause Pénale}

The clause pénale is a unique type of clause. ${ }^{44}$ It operates to secure two somewhat conflicting objectives. Its hybrid character allows it both to encourage performance of contractual obligations and to act as a pre-estimate of damages for breach of a contractual obligation. This unitary form means that (in common law language) a penalty clause and a liquidated damages clauses are integrated as one.

Article 1226 Code civil defines the clause pénale;

La clause pénale est celle par laquelle une personne, pour assurer l'exécution d'une convention, s'engage à quelque chose en cas d'inexécution.

The phrase 'assurer l'exécution' affirms the clause's coercive function. It is to act as a vehicle of constraint, exerting pressure of a psychological nature on the obligor to perform what he has contracted to do. ${ }^{45}$ It is thus evident that a direct in terrorem element is not anathema to the French civilian tradition. ${ }^{46}$ Indeed, its presence is crucial to the very identity of the clause. ${ }^{47}$

The second function that the clause fulfils is found in Article 1229 al.1:

La clause pénale est la compensation des dommages et intérêts que le créancier souffre de l'inexécution de l'obligation principale.

44 J Thilmany 'Fonctions et Révisibilité des Clauses Pénales en Droit Comparé' (1980) 44 Rev Int Dr Comp 17, at 18.

45 Starck et al Droit Civil. Les Obligations Tome 2 (Paris Litec 1998) at 1843. It will be seen in Section IV that the French emphasise the performance of an obligation (exécution en nature) as opposed to an action for damages. The law is equipped with complementary mechanisms to compel, or encourage, performance. Outside the penalty clause rules one finds such things as the astreinte - 'une mesure licite d'intimidation' (Terré et al Droit Civil; Les Obligations (Paris Dalloz 1996), at 1025) - or the mise en demeure (see below n 126).

46 Other civilian systems (eg German, Italian, Spanish, Portuguese) adopt a similar approach.

47 'Une clause n'est ... pénale que si elle a un caractère comminatoire' D Mazeaud, above $\mathrm{n}$ 2, at 85 . See also J Mestre 'De la Notion de la Clause Pénale' RTD civ 1985, 372, at 373-the clause pénale is 'nécessairement comminatoire'. For jurisprudence supporting this; Civ 1er, 22 févr 1977, Bull civ I, no 99, 77. 
Close resemblance with the English liquidated damages clause is manifest here. The clause will fix in advance the amount of damages in the event of default. There is little controversy over this objective of the clause in either jurisdiction. It is 'perfectly legitimate and indeed laudable' 48 to allow the parties to avoid costly, lengthy and hazardous litigation by effectively allocating risk in advance with a pre-estimate of the damages due in case of default. The parties themselves should be able to determine the value of performance. Insurance against the obligor's potential default can be achieved at the lowest cost. The obligee can circumvent potential legal restrictions relating to damages and will not have to prove that he has suffered any loss. ${ }^{49}$ Advantages may also extend to the obligor since he will know of his potential liability if he breaches the contract.

The 1804 Code civil, though owing much to the natural law of the eighteenth century Enlightenment, also gave voice to the newer philosophical and economic order of individualism. ${ }^{50}$ As far as concerns the law of contract, this meant freedom of contract, belief in the sovereign will of the parties and the sanctification of the contractual bond (la force obligatoire du contrat) ${ }^{51}$ The resultant fate for the clause pénale was the prohibition of any judicial revision; since the will of the parties was supreme, any modification of the clause was a violation of this freedom. The inviolability of the clause pénale was pronounced in Article 1152;

Lorsque la convention porte que celui qui manquera de l'exécuter payera une certaine somme à titre de dommages-intérêts, il ne peut être alloué à l'autre partie une somme plus forte, ni moindre.

In this way, although viewed as an assessment of damages, the more intuitive conclusion, 52 that 'compensation' should do no more than 'compensate', seemed to have been subordinated to the will of the parties. ${ }^{53}$

\footnotetext{
48 G Treitel, Remedies for Breach of Contract (Oxford Oxford University Press 1988), at 212.

49 Civ 3e, 12 janv 1994: RTD civ. 1994, 605, obs Mestre.

50 Although, it has been more recently argued that the code wholly subscribes to natural law principles and it is only through later interpretation that individualist philosophies have been given any substance. See A Burge 'Le code civil et son évolution vers un droit imprégné d'individualisme libéral' RTD civ. 2000, 1 and J Gordley, 'Myths of the French Civil Code' 42 Am J Comp Law (1994) 459.

51 Embodied in Art 1134 al 1; Les conventions légalement formées tiennent lieu de loi à ceux qui les ont faites. The complementarity of Arts 1152 al 1 and 1134 al 1 is later underlined in a decision of the Cour commerciale le 2 nov 1967-Bull Civ III, no 351, 333; RTD civ, 1969, 116 et obs J Chevallier, 'la convention ... tenant lieu de loi à ceux qui l'ont faite, il ne peut être alloué à l'autre partie une somme plus forte ni moindre'.

52 Other continental jurisdictions did not grant the same inviolable status to the penalty clause as France. For example, Italy (Art 1134 c.civ), Switzerland (Art 163 C. Federal des Obligations) and Germany ( $\$ 343 \mathrm{BGB})$ all allowed the sum to be reduced by the courts where it was exces-

53 The conception of the clause as an assessment of damages means that the obligee cannot demand the penalty in addition to performance or damages. This contrasts with the German provision $\$ 340$ BGB which provides that the penalty clause is a minimum sum and does not preclude an action for damages if actual loss is more.
} sive. 
There was, however, an exception to the notion of la force obligatoire du contrat which is found in Article 1231. The judge is given a legal base to modify the contractual penalty where the parties have only provided for total non-performance and breach has only been partial. ${ }^{54}$ But this exception is subject to a 'counter-exception' ${ }^{55}$ Article 1231 was not d'ordre public, which meant that the parties could stipulate otherwise and circumvent its application. Thus, in practice, the exception became extremely limited.

But the development of industrial capitalism and large scale economies would inevitably lead to a remodelling of legal frameworks constructed in a period where such concepts were largely imaginable. Mass production and distribution through global networks demands a change in the conventional model of contractual relations. The commercial expediency of standard form contracts, which require no authentic negotiation, have marginalized, if not almost replaced, the contract tailored to the particular needs of the individual. The resultant widespread occurrences of contractual disequilibrium was not something that the drafters of the Code civil had envisaged. There was thus little protection to be found in Article 1152 for the unwitting and imprudent obligor (often a consumer) 'tyrannised' 56 by draconian terms in the form of clauses pénales. The courts were impotent to alleviate even the most blatant abuses of creditor power ${ }^{57}$ confronted with the system's subordination of equity to legal certainty. Their efforts were in vain. The proliferation of hire purchase and rental agreements provided particularly fertile ground for scandalous penalty clauses. ${ }^{58}$ But litigation founded on notions such as justice, equity, absence of cause or prohibition of usury under the Loi du 28 décembre 1966 all met with the resistance of the Cour de cassation. ${ }^{59}$

The Loi du 9 juillet 1975 was an attempt to resolve this battle between law and equity and control the widespread abuse. A second paragraph to 1152 was inserted, entrusting the judges with a pouvoir modérateur;

Néanmoins, le juge peut modérer ou augmenter la peine qui avait été convenue, si elle est manifestement excessive ou dérisoire. Toute stipulation contraire sera réputée non écrite.

Article 1152 al 2 thus allows the judge to intervene and either increase or decrease (the latter being the most usual) the sum where it is manifestly excessive or derisory. The parties are not able to contract otherwise. The reform thus

\footnotetext{
54 'La peine peut être modifiée par le juge lorsque l'obligation principale a été exécutée en partie.'

55 B Boccarra 'La Liquidation de la Clause Pénale et la Querelle de l'article 1231 du Code Civil' JCP 1970 I 2294, at para 9.

56 S Sanz 'La Consécration du Pouvoir Judiciaire par la Loi du 9 juillet 1975 et ses Incidences sur la Théorie Générale de la Clause Pénale’ RTD civ. 1977, 268.

57 Thilmany above n 44 and Mazeaud above n 2 talk of 'contractual terrorism'.

58 For a particularly harsh case concerning a rental agreement see Com et Fin, 2 novembre 1967, Bul 1967, III, n 351, 333.

59 The Court did express regret at the principle of non-intervention in its 'Rapport au Garde des Sceaux' 1972-3 demanding reform of the texts that it felt bound to follow.
} 
subordinates the parties' clear expression of volition to the discretionary power of the judge. It represents a subtle but perceptible shift in the hierarchy of values hitherto postulated in legal theory. ${ }^{60}$

Article 1231 was entirely reformulated;

Lorsque l'engagement a été executée en partie, la peine convenue peut être diminuée par le juge à proportion de l'intérêt que l'exécution partielle a procuré au créancier, sans préjudice de l'application de l'article 1152. Toute stipulation contraire sera réputée non écrite.

As seen, Article 1231 regulates a partially performed obligation allowing the judge to reduce the sum, without prejudice to Article 1152, in proportion to the benefit gained by the injured party. But even such pro rata enforcement may be oppressive and so the sum can first be reduced on the ground that it is manifestly excessive and then further reduced on the ground that the obligation has been partly performed. The faculty for derogating from this is now outlawedany such stipulation will be disregarded.

Judicial control to supervise a contract that aims to threaten one of the parties with a penalty might be welcomed in a modern legal system. It establishes a cushion of protection for those less equipped to manage the increasing complexities of everyday transactions and who find themselves at the mercy of commercial wiles. But, if equitable powers are conferred on the judge to intervene in the 'law of the parties', a decline in the concept of la force obligatoire du contrat must however be accepted as the first casualty. ${ }^{61}$ The second, related casualty will be the coercive force of the clause pénale. A potential defaulter may be emboldened by the possibility of judicial modification of the sum and thus more likely to breach the contract. The weakening of the repressive element, essential to categorisation of the clause as a penalty, prompted one author to announce the 'death' of the clause. ${ }^{62}$ Another immortalised its passing away in an article entitled 'Requiem pour une clause pénale'. ${ }^{63}$ Can one only conclude that the reform has marked the end of the penalty clause?

The judicial approach to the clause pénale and the way that discretion is exercised plays an essential part in the operation of the clause and is largely determinative of its future role in the legal system. This is as true for the

\footnotetext{
60 The power of the judge has been seen as resting more on a notion of equity than that of law. Armand-Prevost and Richard 'Le Contrat Déstabilise (De L'Autonomie de la Volonté au Dirigisme Contractuel)' JCP 1979 I 2952, at para 19. Nevertheless the reform affirmed the importance of judicial powers in private contractual relations; Mazeaud above $\mathrm{n} 2$, at 30 .

61 'Une brèche a ainsi été ouverte en 1975 dans le principe de la force obligatoire des conventions'; G Paisant 'Dix ans d'Application de la Réforme des Articles 1152 et 1231 du Code Civil Relative à la Clause Pénale (loi du 9 juillet 1975)' RTD. civ 1985. 647, at 4. F Chabas - considers that the law is 'une des premières entorses importantes apportées à l'article 1134 du Code civil' 'La Réforme de la Clause Pénale' D 1976 Chron 229.

62 B Boubli ' La Mort de la Clause Pénale ou le déclin du principe de l'autonomie de la volonté' J not 1976. 1.945.

63 Y Letartre 'Requiem pour une Clause Pénale?’ Rev Jur Com (1978) 101.
} 
common law as it is for the civil. The extent to which intervention can be allowed to infringe the parties' freedom will be dictated by society's competing moral, socio-economic and legal beliefs and will highlight the legal system's hierarchy of values of the period. But the fate of the penalty clause is not solely contingent on national considerations. European Community values have asserted their presence, a principle vehicle in this area being the EC Directive on Unfair Terms in Consumer Contracts. The impact of this EC legislation on the penalty clause rules and the concomitant consequences for the judicial role will be examined in Part V. First the traditional judicial role must be analysed.

\section{THE ROLE OF THE JUDGE}

\section{A. The Nature of Discretion}

The discretionary power of the French judge operates at three complementary levels each of which is crucial for the continuing vitality of the clause pénale. An examination of the scope of this discretion, with comparative analysis, discloses the considerable role of the judiciary ${ }^{64}$ and the concern to ensure the binding nature of the contract in both jurisdictions. It also questions the assertion that the civilian judge only applies the law leaving the more pragmatic, creative work to his English counterpart.

Strict division of each level at which discretion operates is highly artificial but is helpful for expository purposes.

\section{Classification}

The requisite composite nature of the clause pénale means that a clause lacking one function, whether it be the coercive or compensatory function, is not classified as a clause pénale and is thus not subject to the modification power of the courts. The 1975 reform engendered much debate concerning the scope of the judicial powers encapsulated in 1152 al $2 .{ }^{65}$ It seems that, whilst academic opinion was (and remains) in favour of an interpretation that extends the power generally to clauses that consist in an assessment of damages, judicial recognition of this is still somewhat hesitant. ${ }^{66}$ Reduction in accordance with 1152 al 2 for the moment remains the exclusive domain of the clause pénale.

Classification of a clause as pénale therefore becomes crucial for the

\footnotetext{
64 It is interesting to draw attention to this powerful judicial role bearing in mind that one purpose of the clause pénale is to obviate judicial evaluation of damages.

65 See Mestre above n 47, at 372 et seq; Mazeaud above n 2, 145 et seq; Dagorne-Labbe 'Rejet de la demande de réduction de l'indemnité contractuelle de résiliation due au mandataire' JCP 2002 II, 10067.

66 See, eg, case D 1996 Somm 329, obs Mazeaud where the court refused to extend the ambit of 1152. al 2 .
} 
obligor desirous of the protection of the court. And it is here that resemblance with the common law is striking. The court will look to the intention of the parties at the moment of the conclusion of the contract to classify the clause. ${ }^{67}$ Anxious to preserve the binding force of the contract and not to sacrifice legal certainty too readily to the guiles of equity, the courts (monitored by the Cour de cassation) are strict in their interpretation.

Perhaps surprisingly, the practical effect in England of the penalty clause rules is not dissimilar to that of France, despite the opposing theoretical starting points. The inflexible approach of orthodox theory that does not accommodate any penal element in a clause has repercussions on the classification process initially undertaken. In practice the courts will not be over-zealous or 'astute' 68 to characterise a clause as oppressive or penal. ${ }^{69}$ There are clearly commercial benefits of allowing the parties to know with as much certainty as possible the risks they face when they enter into a contract, ${ }^{70}$ and inordinate intervention will be deleterious for business dealings each time that it compromises predictability. ${ }^{71}$ Where the clause has clearly been concluded between parties of equal bargaining strength it will often not be classified as penal. In the absence of a need to protect a weaker party the bargain will be respected and the clause upheld where possible. In the search for the parties' intentions the objective test of intention can be discreetly manipulated to further this policy. Moreover, the Dunlop guidelines set a high threshold for denomination as penal-the sum must be 'extravagant and unconscionable' in relation to the 'greatest possible loss' that could be suffered by the obligee. Judicial enforcement of a clause is thus maximised.

\section{Facultative Power}

The second stage at which discretionary power crystallizes in France can be seen to be the backbone of the 1975 reform. Article 1152 al 2 articulates the facultative nature of the intervention; 'le juge peut modérer ou augmenter la peine' ${ }^{72}$ Thus, even in the presence of a clause pénale the juge $d u$ fond can decide whether or not to intervene in the parties' bargain and modify a manifestly excessive or derisory sum. ${ }^{73}$ Furthermore, the 1985 amendment to

67 Mazeaud above n 2, at 148. Chabas Leçons de Droit Civil; Tome II Obligations (Montchrestien 1998), at 772 states that apart from certain clauses whose identity is settled -l'indemnité d'immoblisation and la clause de dédit-the court will look the intention of the parties. The parties' denomination of the clause is not determinative.

68 As per Lord Diplock, in Robophone above n 26, at 142.

69 '[W]hat the parties have agreed should normally be upheld' Philips Hong Kong Ltd v A-G of Hong Kong, above n 19, at 59.

70 Ibid and Lord Diplock in Robophone, above n 26, at 142.

71 See Privy Council judgment of Union Eagle Ltd v Golden Achievement Ltd [1997] AC 514.

72 My emphasis.

73 The judge not only decides whether to intervene but also evaluates whether the conditions for intervention are present-in other words whether the sum is manifestement excessive-arrêt de la Première Chambre civile-24 juill 1978 Gaz Pal 8, 9 déc 1978. 
Article 1152 al $2^{74}$ accords him the power to intervene même d'office-in other words without the request of the parties. If he decides not to intervene, he does not even have to justify (motiver) his decision.

The facultative character of intervention preserves the coercive function essential to the French clause pénale ${ }^{75}$ It acts to counter the criticism by even the most pessimistic commentators that the reform has stripped the mechanism of its substance, leaving it as a simple evaluation of actual loss. The facultative power imbues the clause with a dissuasive ambiguity - the prospect of judicial inaction gives the clause its coercive character.

Of course discretion is not unlimited. The Cour de cassation has formulated certain guidelines to assist the juge $d u$ fond in his evaluation and to maximise consistency. They combine objective and subjective considerations. ${ }^{76}$ As well as the difference between the sum stipulated and the actual loss suffered, the factors considered include such things as the amount that the clause is trying to guarantee; the inequality of bargaining power; the economic situation of the obligor; whether he is in good faith and even his state of health. ${ }^{77}$ These broad factors accentuate two things; the element of unpredictability in intervention (further preserving the coercive aspect) and the ease with which French law deals with abstract, subjective concepts. (The significance of this latter point on the formation of the penalty clause rules will be rejoined below.) Such concepts present difficulties for the common law mentality that favours a more commercial underpinning to the exercise of discretion.

\section{Amount of Reduction}

At the third level of enquiry, where the judge does exercise his power of intervention, then the amount of the reduction (or increase) of the penalty is within his discretionary powers. Again, however, these powers are not unlimited. The amount of actual loss will constantly operate as an axis of reference; the judge must not award less than the actual loss suffered, ${ }^{78}$ and it has even been held that the court must not reduce the amount to that of

74 Loi no 85-1097 du 11 oct 1985.

75 This point is punctuated by comparison with the Swiss legislative provision which provides, 'le juge doit reduire les peines qu'il estime excessives'. [my emphasis]

76 The explicit inclusion of subjective values contrasts with the common law orthodoxy that the judge must work within solely objective confines.

77 It is submitted that since assessment can openly incorporate all factors up to the time of the judgment-and not just the circumstances at the contract's conclusion-appreciation of the subjective element is facilitated. The contrast with the English rejection of subjective concerns is noteworthy. Dillon LJ, in Jobson v Johnson, above n 28, at 1033 (referring to Wallingford v Mutual Society (1880) 5 App Cas 685, at 702) states that neither the financial circumstances nor the extent of culpability of the mortgagor were relevant to relief from enforcing the penalty. Nicholls LJ (at 1041) considered the 'circumstances of the default' immaterial.

78 G Cornu 'Clause Pénale; principle, limite et conséquence de l'appreciation souveraine par les juges du fond, du caractère manifestement excessif de la peine stipulée et du montant de la modération' RTD civ 1979. 150. 
actual loss. ${ }^{79}$ This latter interpretation is preferable since, if the sum were reduced to an amount equivalent to (or even below) actual loss, then the judge's power would be more appropriately classified as a sanction and not a reduction ${ }^{80}$ and would seem contrary to a conception of 'peine'. Where there is no loss then an action for the penalty will be rejected. ${ }^{81}$ For the common law, theoretically the judge only considers the intention of the parties at the time of contracting (see above) and consequent loss should be irrelevant. Absence of loss however would be likely to be influential in the assessment of whether it was a genuine pre-estimate of loss. It is thus likely that the jurisdictions would often approach each other in result.

The role of the judge is thus crucial to the effective operation of the penalty clause rules in both jurisdictions. It will be seen that whilst the EC Directive on Unfair Terms ${ }^{82}$ has had disruptive consequences for the rules in France and England, the judicial role will remain pivotal to the eventual form and place that the penalty clause occupies in each legal system. But whilst EC legislation might sit uncomfortably within national frameworks, it would be misleading to suggest that such frameworks were already formulated in a wholly consistent and logical form. When viewed within a broader context, the interaction of the penalty clause rules with other areas of contract law produces a mass of contradictions and inconsistencies that are difficult to defend.

\section{INCONSISTENCY}

A clause in a loan agreement whereby a sum of money is to be paid over a period of time by way of instalments may stipulate that on default of any one payment the entire principal becomes due. Increased psychological pressure on the obligor to perform his obligation is clearly discernible. The benefit of structured payments granted under the contract is replaced by the disadvantage of early payment which will often be more expensive to the obligor. He will therefore feel pressured to a greater or lesser extent not to breach the contract. Nevertheless this mechanism, known as an 'acceleration clause,' is acceptable in England.$^{83}$ Provided that there is no increase to the liability of the obligor, ${ }^{84}$ the Dunlop rules are not applicable. An identical approach is taken in French

\footnotetext{
79 Cass com, 23 janv 1979, Bull civ IV, no 30; CA Amiens, 23 nov 1976, JCP 1977.II.18567, note EMB.

80 'Modérer n'est pas supprimer' Paisant; $D$ 1991, 481, at 13.

81 Com, juill 1991, D 92, 365.

82 See Section V.

83 White \& Carter (Councils) Ltd v McGregor, above n 42; The Protector Endowment Loan Co $v$ Grice (1880) 5 QBD 529. It is not the purpose of this paper to evaluate the commercial efficacy or desirability behind this mechanism, rather to highlight the fact that a penal element is seen as acceptable.

${ }^{84}$ In other words, a provision that stipulated for interest for the whole contractual period as well as accelerated payment would be considered penal. See The Angelic Star [1988] 1 Lloyd's Rep 122, at 125.
} 
law. Since the term only re-establishes the pre-contractual status quo without adding to the liability of the obligor, it is not considered a clause pénale and is thus excluded from the ambit of Article 1152 al $2 .{ }^{85}$

The potential for termination of further performance of the contract provides another powerful example of where English law may be said to sanction a penal element in a contract. A party has a right to terminate a contract in two situations. The general rule is that breach of a condition or innominate term, where the consequences of that breach are sufficiently serious, ${ }^{86}$ may entitle the injured party to terminate further performance of the contract. Secondly, in theory, ${ }^{87}$ the parties may stipulate that any breach of a particular obligation (irrespective of the actual consequences) entitles the injured party to terminate the contract, giving the injured party a much wider power to terminate. The injured party has the choice as to whether he affirms or terminates the contract. There is no need for judicial intervention (such as under Article 1184 al 3 Code civil) ${ }^{88}$ It is only if the defaulting party contests the termination that the court will need to rule on the seriousness of the breach. ${ }^{89}$ The injured party is thus endowed with a powerful legal tool of self-help, ${ }^{90}$ the obvious counterpart of this being a potent disincentive for his contracting party to breach his obligations. The loss to the obligor from unilateral termination of the contract by the obligee is potentially greater than what would be recoverable by the obligee in an action for damages. He stands to lose any expected benefits from the obligee's future performance as well as any expenditure already incurred in the performance of his obligations under the contract, if he is unable to pass this on to a third party. ${ }^{91} \mathrm{He}$ is thus strongly 'persuaded' to perform his side of the bargain.

There is a certain paradox in the termination rules which highlights the contradictions with the penalty clause rules. The rules rest on the assumption that termination satisfies commercial considerations of efficacy. But the obvious corollary is the inherent coercive element that will dissuade the potential defaulter from breaching. In France, it is axiomatic that the termination rules have a repressive effect $^{92}$ which only emphasizes the common law discrepancies. Perplexingly the law works to encourage performance of contractual duties whilst viewing penalty clauses with animosity for doing just that. The rule cannot be satisfactorily

85 Civ 1re, 22 fév 1977 Bull civ I, no 99.

86 Hongkong Fir Shipping Co Ltd v Kawasaki Kisen Kaisha Ltd [1962] 2 QB 26.

87 See below n 90 and $\mathrm{n} 91$ for qualifications to this rule.

88 La résolution doit être demandée en justice.

89 Thus the onus of initiating litigation shifts to the obligor.

90 Although where breach of a 'condition' occasions negligible damage the court may hold that termination is not justified; Wickman Ltd v Schuler AG [1974] AC 235. See also Rice v Great Yarmouth BC (2001) 3 LGLR 4 where the Court of Appeal refused to recognize a termination clause which extended to multiple types of obligation under a 4-year contract.

91 In practice, the courts will have regard for the consequences that termination will have for the obligor in determining whether a breach is sufficiently serious to justify termination by the obligee.

92 See, eg, Mazeaud above n 2, at 63. 
explained by mere reference to the fact that judicial control tends to be more stringent over judicial remedies (penalty clauses) as opposed to its more liberal attitude towards self-help. ${ }^{93}$ The contradictory legal messages are disquieting.

Further common law incoherence concerns the requirement of breach - it is only where there is a breach of the contract that the law relating to penalties is relevant. A sum due on the occurrence of any other event cannot therefore be covered under these rules. ${ }^{94}$ This can have important consequences in the area of hire purchase agreements and the so-called minimum payment clauses. Where the agreement is determined on an event other than breach (eg, where the hirer exercises his right to return the goods) then the law of penalties does not apply. ${ }^{95}$ Faced with a draconian minimum payment clause, the hirer will have more of an incentive to breach the contract and be included within the more protective regime of the law of penalties. ${ }^{96}$ This solution can hardly be satisfactory and the resulting injustice is clearly voiced by Lord Denning in Bridge v Campbell Discount Co Ltd.$^{97}$ Such an anomaly has no place in a rationally constructed legal system.

The requirement of 'breach' (or, in civil law terms, non-performance) of contract for application of the clause pénale rules arouses similar difficulties in French jurisprudence. The penumbral boundary line between an amount due on breach, or in the exercise of a right, is jealously guarded by the Cour de cassation who will reproach the juge $d u$ fond for modifying a clause when there is no breach. A good example is the indemnité d'immobilisation, which is the sum payable by the beneficiary of a purchase option to ensure that the vendor does not sell to anyone else or retract his offer throughout the duration of the option. Since the beneficiary is under no obligation to purchase, the decision not to do so is not considered a breach. The penalty clause rules are thus inapplicable ${ }^{98}$ and the amount payable (normally subtracted from the purchase price when the option be exercised) is not subject to any judicial modification.

93 See Friedmann 'Good Faith and Remedies for Breach of Contract' in Beatson and Friedmann (eds) Good Faith and Fault in Contract Law (Oxford Oxford Univeristy Press 1995) and R Goode 'Europe and English Commercial Law' in Markesinis (ed), The British Contribution to the Europe of the Twenty-first Century. British Academy Centenary Lectures (Oxford Hart 2002) 19. It should also be borne in mind that judicial assistance may be required to work out the consequences of termination. Thus, the distinction between self-help and judicial remedies can be slight.

94 A good example is Alder v Moore [1961] 2 QB 57. A sum due to an insurance company if a professional footballer returned to the sport after an injury was not a penalty. There was no breach on his return to the sport since he had not promised otherwise. As far back as 1975 a Law Commission Working Paper (No 61) recommended that the "court should have the power to deal with such clauses in the same way whether or not they come into operation by breach' (para 22). It further proposed that the penalty clause rules should apply 'wherever the object of the disputed contractual obligation is to secure the act or result which is the true purpose for the contract' (para 26).

95 Associated Distributors Ltd v Hall [1938] 2 KB 83 and Bridge v Campbell Discount Co Ltd, above $\mathrm{n} 22$.

96 Where the contract is governed by the Consumer Credit Act 1974 then this may not apply.

97 Above $n$ 32. Here the judges were able to find the hirer in breach of contract to release him from liability. In this case the result furthered the general policy underlying the law relating to penalties. But it is a rather precarious basis on which to proceed should the facts of the case differ.

98 Civ 3e, 5 déc 1984 D 1985.545 et note Benac-Schmidt. 
A contract stipulating for a sum of money payable on breach of another contract with a third party is likewise not included in the law of penalties in either jurisdiction. This is the case even though the sum due would, on breach of the contract between the obligor and obligee, be considered penal. ${ }^{99}$

Perhaps the most anomalous common law example occurs in the rules relating to 'forfeiture clauses'. Where money is paid in advance of performance, the question of whether it is recoverable on breach depends on how the contract is constructed. Different consequences flow from classification of the payment under the clause as either a deposit or a part payment. ${ }^{100}$ As a general rule, a deposit will be forfeited to the payee on the default of the payor, ${ }^{101}$ whereas a part payment can be recovered from the payee. ${ }^{102}$ Clearly, where the court considers the payment to be a deposit, the loss to the payor is capable of being much more than the actual loss suffered by the payee. This seems to fly in the face of the penalty clause rules since the payor could sometimes be subjected to what can only be described as an extremely harsh 'penalty'. Even the definition of a deposit reiterates its innately coercive nature - it is a payment that acts as a guarantee that the contract shall be performed. ${ }^{103}$

The harsher aspects of the rules on deposits have been somewhat mitigated by the Workers Trust case. ${ }^{104}$ It was established that the law of penalties will in fact apply. ${ }^{105}$ But this is only where a deposit is 'unreasonable' in relation to the loss likely to be suffered and a deposit for the sale of land that does not exceed 10 per cent ${ }^{106}$ was considered as entirely reasonable. ${ }^{107} \mathrm{~A}$ 'reasonable' deposit could therefore still be a sum that is not a genuine pre-estimate of loss and could still take effect as a penalty 'albeit one permitted by law' ${ }^{108}$ Homogenisation of the two sets of rules is thus prevented. ${ }^{109}$ Furthermore,

99 Export Credits Guarantee Department v Universal Oil Products, above n 8 and Civ 1re, 16 janv 1985 JCP 1986 II 20661 et note Paisant.

100 The court will look at the intention of the parties to determine their objectives; Mayson $\mathrm{v}$ Clouet [1924] AC 980, at 985.

101 Howe v Smith (1884) 27 Ch D 89.

102 Mayson $v$ Clouet above $\mathrm{n} 100$. However the issue of whether a part payment is recoverable will be subject to the standard of unconscionability. See Stockloser v Johnson [1954] 1 QB 476.

103 Linggi Plantations Ltd v Jagatheesan [1972] 1 MLJ 89 at 94. It is interesting that this definition replicates one given to the French clause pénale in an attempt to distinguish between that and a clause de dédit: une clause pénale 'est la garantie des obligations contractuelles'Mazeaud D 29996 Somm 329. (A clause de dédit can be broadly translated as a 'forfeiture clause'. It is seen not as a guarantee to perform but as the payment by the obligor for the freedom to unilaterally withdraw from the contract without incurring liability. It is the exercise of a right as opposed to the English breach of an obligation).

104 Workers Trust and Merchant Bank Ltd v Dojap Investments Ltd [1993] AC 573.

105 The 1975 Law Commission's Working Paper No 61 had proposed that control over penalty clauses should be extended to forfeitures and deposits (paras 64-6).

106 This percentage, although 'without logic', was used as a benchmark since it was normal practice in contracts for the sale of land.

107 Unless special circumstances prove otherwise.

108 As per Lord Browne-Wilkinson in Workers Trust, above n 104, at 580.

109 Although there is scope for the argument that 'unreasonable' can be equated with 'unconscionable' under the first Dunlop rule. 
even though the penalty clause rules are said to apply, this does not mean that the same legal consequences follow. An unreasonable deposit is not 'scaleddown' 110 to the extent that it is not reasonable. Instead the payee must repay all of the monies deposited plus interest. ${ }^{111}$

The pre-eminence accorded to freedom of contract is common to France and England in this area. In France, since the sum paid under a clause de dédit $^{112}$ is considered the price for the ability to withdraw from the contract, it is not considered a breach of any obligation and is thus removed from the domain of Article 1152. The paradoxical consequences of this prove that England is not alone in illogical rules; the obligor who is in breach of his obligation will be extended the equity of the judge and could have his penalty reduced; the obligor who is not viewed as being in breach (under a clause de dédit) will be denied this advantage and will forfeit the whole sum paid.

The working similarities in the civilian and common law penalty clause rules have been highlighted throughout this essay. It is now clear that both systems also suffer from similar inconsistencies. But it is the common law approach which presents the most theoretical difficulties by explicitly prohibiting a penalty clause, by reason of its coercive nature, while at the same time implicitly tolerating a coercive element in other clauses. The clash of respect for party autonomy with socio-economic and moral theories which attack the pre-eminent position of the individual, leads to rules operating in isolation of each other and a law that 'embodies the language of dichotomy'. ${ }^{113}$ As new theories develop old ones need to be discarded if coherence is to be achieved ${ }^{114}$ and alignment reached between what the law says with what it does. The next part addresses the question as to why the common law maintains theoretical resistance to upholding an agreed damages clause that acts to reasonably 'persuade' the obligor to perform, even where such clause is a clear expression of the parties' intentions.

\section{IV. 'REMEDIES LAW' AND GOOD FAITH AS EXPLANATIONS FOR THE DEVELOPMENT OF THE PENALTY CLAUSE RULES}

\section{A. 'Remedies' for Breach of Contract}

Much can be learnt from an examination of the different approach taken when one party fails to do what he is contractually bound to perform. In common

\footnotetext{
110 Following the Jobson $v$ Johnson rules on penalty clauses.

111 He will though be able to recover damages for any loss suffered from breach.

112 Defined above n 103.

113 L Dimatteo 'A Theory of Efficient Penalty; Eliminating the Law of Liquidated Damages' 38 Am Bus LJ (2001) 633, at 635.

114 Ibbetson, above n 3, at 245.
} 
law terminology this means a comparative examination of the remedies ${ }^{115}$ available to the plaintiff. Legal orthodoxy in each system takes opposing theoretical sides. ${ }^{116}$ The choice between specific performance (exécution en nature) and monetary compensation, can be crudely stated as the distinction between 'compulsion' and 'relief' ${ }^{117}$ It is generally accepted that, in principle, French law (in common with other civilian systems) adopts the former stance, that of compulsion, allowing the contractor to demand performance in specie. ${ }^{118}$ In contrast, the common law adopts the latter position, according primary status to the action in damages for breach of contract - a monetary award.

For the common lawyer 'the duty to keep a contract ... means a prediction that you must pay damages if you do not keep it-and nothing else'. Notwithstanding its rhetorical style, this much-cited quotation of Holmes is useful to demonstrate the common law frame of mind. Traditional doctrine focuses less on the nature of the practice and more on the remedy or, more specifically, less on the nature of the rights and duties that are at its core and more on the entitlement to remedial satisfaction. ${ }^{119}$

The French theory of 'remedies' however is predicated on the logically prior examination of the right of the obligee to receive performance and thus the corresponding duty of the obligor to perform. In France a contract is viewed much more as a joint undertaking and breach considered a moral 'wrongdoing'. ${ }^{120}$ Historical influences have resulted in epistemological differences in the conception of contract in the civil and common law ${ }^{121}$ which in turn has repercussions for the area of 'remedies'. The etymological significance of the word 'obligation' from the Roman obligatio denotes a 'tying

\footnotetext{
115 This is common law terminology. Whereas in England the law of 'remedies' is treated as a coherent set of legal principles, in France, the same area of law is instead incorporated in different chapters and sections of the Code civil and analysed as the effects of the contract or obligation rather than a wholly separate legal category. Although the difference is principally only one of structure, it does draw attention to the different approaches (see B Nicholas The French Law of Contract (Oxford Oxford University Press 1992) 211).

116 It should be stressed that the discussion in this section represents the traditional theoretical positions. Legal systems do not remain static and trends have meant that in practice, despite the different emphasis, the systems often arrive at the same results. The types of contract which are specifically enforced in France and England 'share common characteristics'; Ogus 'Remedies. 1. English Report' in Harris and Tallon (eds) Contract Law Today; Anglo-French Comparisons (Oxford Clarendon Press 1989) 243. Despite modern trends examination of the traditional approach is of course imperative to an understanding of the underlying legal structures and 'attitudes of mind' (Nicholas ibid, at 211) that have formed the penalty clause rules.

117 Farnsworth 'Legal Remedies for Breach of Contract' Columbia L Rev (1970) 1145.

118 Despite the suggestion in Art 1142 that damages are the primary remedy (for an obligation de faire or de ne pas faire) the principle is subject to numerous qualifications and a juristic interpretation that has reduced it to an exception.

119 Davy v Spelthorne BC [1983] 3 All ER 278,185 per Lord Wilberforce, 'Typically English law fastens not on principles but remedies.'

120 Ogus above n 117, at 293.

121 See on this generally, A de Moor 'Common and Civil Law conceptions of Contract and a European Law of Contract; the Case of the Directive on Unfair terms in Consumer Contracts' European Review of Private Law (1995) 257.
} 
together' (ligare) of bonds between the obligor and obligee, an essentially bilateral relationship which is significant when viewed from either side of the contractual relationship. This is reflected in civilian understanding; for the obligor, 'obligation' denotes the duty to perform the obligation and for the obligee it denotes the right to receive performance. It differs in this way from the English understanding of 'obligation' where duty is perceived solely from the obligor's viewpoint. ${ }^{122}$

This has important consequences. In France, once the contract is formed it binds the parties in a shared undertaking ${ }^{123}$ and the law is concerned to ensure that the parties keep to their bargain. If the obligor does not perform, rather than immediate resort to damages for breach, the law will instead employ various legal means to compel him to do so. It is only where these fail, or where such means are not available, that the question of substitutionary relief in the form of damages arise. ${ }^{124}$

The framework of the Code and doctrinal reasoning is heavily impregnated with a commitment to the binding quality of contracts and la liberté contractuelle, principles at their apogee at the time of the drafting of the Code. It provides the conceptual link between specific performance and penalty clauses; where the primary objective is to have the contract performed there is little sense in categorical disapproval of a mechanism aiming to ensure this objective. The penalty clause rules are structured to secure performance of the contract in two simple ways; first, through acceptance of the penal element, and secondly, through Article 1228 Code civil which ensures that the presence of a penalty does not preclude the obligee from demanding performance instead-[l]a créancier, au lieu de demander la peine stipulée ... peut poursuivre l'exécution de l'obligation principale. ${ }^{125}$

Pacta sunt servanda and the Will Theory have, of course, been inspirational principles in the common law ${ }^{126}$ but they suggest a stronger concern

122 It is suggested that the term 'remedies' accentuates the common law focus on only one side of the contractual relationship - the obligee's. In France conceptualization as les effets du contrat presupposes rules relating to both obligor and obligee.

123 Picod, 'L'Obligation de coopération dans l'exécution du contrat' JCP 1988 I 3318, visualises the contract as an obligation of cooperation. Kötz believes French law 'ranks solidarity higher than individualism' 'Towards a European Civil code; The Duty of Good Faith' in P Cane and J Stapleton (eds) The Law of Obligations; Essays in Celebration of John Fleming (Oxford Clarendon Press 1988) 256. This concept of contract is not fitting for an adversarial system such as the common law.

124 When the French do talk of damages it is perceived as a substitute for actual performance rather than simply compensation for the loss of bargain, reflecting the French emphasis on performance.

125 The French requirement of the mise en demeure (Art 1146) whereby the injured party, acting through a huissier, must serve a formal notice on the defaulter is another example of the importance of performance in France. In practice it will work to give the obligor one last chance to perform. The nineteenth century judicial innovation known as the astreinte, likewise, is geared towards ensuring performance. It imposes a monetary sanction for each day of non-compliance with the contractual obligation.

126 Although apart from the dicta in Printing and Numerical Registering Company v Sampson 
with the commercial and individualist elements of the contractual relationship as opposed to the moral element so evident in France. In England the highly commercial roots of contract law promote certainty as the higher societal value $^{127}$ and even where concerns of 'morality' enter the contractual equation through equitable principles, it is based more on normal standards of commercial probity than abstract moral values. ${ }^{128}$ When the contract is breached, commercial needs will be normally satisfied in the form of damages, rather than legal mechanisms to encourage performance.

An award of damages rather than specific performance can be further rationalised through the language of economics; by granting only monetary relief to the obligee, rather than compelling performance, contract law allows resources to flow freely to higher valued uses at the lowest possible loss. ${ }^{129}$ It is therefore not economically rational for the law to accommodate any mechanism (such as the penalty clause) that acts to coerce (or persuade) the obligor to perform. In this way, intolerance of penalty clauses is justified and judicial intervention defended. ${ }^{130}$

But, whilst the emphasis on damages, as opposed to performance of the contract, has been influential in the formation of the penalty clause rules one other factor is proposed as significant. Interwoven into the fabric of the French Code civil is a recognition of abstract concepts of morality and good faith. There is neither a general principle of good faith in English law nor the same importance given to subjective values as can be seen in France. This has implications for the law's treatment of penalty clauses.

\section{B. Good Faith and Unconscionability}

The initial French rejection of any judicial intervention in the contract before the 1975 reform confined bonne foi to an inconsequential role despite its

(1875) LR 19 Eq 462 as per Sir G Jessel, MR, at 465, adherence to the Will Theory is perhaps usually more a question of objective interpretation rather than formal, explicit judicial acknowledgement.

127 By 'certainty' is meant the formulation of clear rules that enable forward planning and risk assessment rather than the systemic certainty that comes with the preservation of the contractual obligation itself.

128 Harris and Tallon (eds), above n 116, at 386.

129 This is the basis for the so-called 'efficient breach' theory advocated by Posner in Economic Analysis of Law (5th edn New York Aspen Law \& Business 1998). Where the breaching party will still be better off by the breach, even after paying damages to the 'innocent' party, then economic theory regards this as a positive thing. Thus, a contracting party should be free to breach and not be compelled to perform the obligation.

130 This brief foray into economic analysis cannot do justice to the complexity of this area. Nor does it give adequate voice to the persuasive counter-arguments of many commentators. See, eg, Rubin 'Unenforceable Contracts: Penalty Clauses and Specific Performance' 10 (1981) J Legal Studies 237; Goetz and Scott 'Liquidated Damages, Penalties and the Just Compensation Principles: Some Notes on an Enforcement Model and a Theory of Efficient Breach' 77 Colum L Rev (1977) 554; Clarkson et al, above n 45. 
prominent positioning in the Code civil. $^{131}$ Although Article 1134 al. 3 prescribes that les conventions doivent être exécutées de bonne foi, the force obligatoire du contract suppressed any competing notions of justice and fairness in the form of a general doctrine of bonne foi. ${ }^{132}$ The 1975 reform facilitated a rise in importance for bonne foi. ${ }^{133}$

But the textual simplicity of Article 1134 al 3 belies the polemical past and unsettled future for bonne foi. Despite explicit reference in Article 1134 to the performance of the obligation, any definition of bonne foi has been vague and fluctuating which has contributed to its percolation throughout the life of the contract, from the pre-contractual to the post-contractual stages. Its amorphous nature is recapitulated by Tallon: '[l]a bonne foi est quelque chose que l'on sent plûtot que l'on peut enfermer dans une définition rigide. Seule est possible une définition souple ou même plusieurs .... ${ }^{134}$ The concept has become so general that it has been interpreted, among other things, as a moralisation of contract law, ${ }^{135}$ as representing a duty of collaboration ${ }^{136}$ and of loyalty. ${ }^{137}$ This ill-defined and imprecise view has not been universally welcomed because of its tendency to encourage judicial rewriting of agreements and create unnecessary uncertainty. ${ }^{138}$ However there does not seem to be any disquiet regarding the dangers of introducing social and moral values into private contractual relations - something problematic for the more 'economic and more pragmatic'139 English law.

Bonne foi is important to the discussion on penalty clauses. It is submitted that its presence mitigates the more intolerable aspects of a penalty imposed between parties and renders the mechanism acceptable even in a philosophical climate that advocates protection for the individual and social justice. An infusion of subjective values (albeit accompanied by contractual uncertainty) allows the objectionable ingredient of coercion to be controlled by the judiciary. The court can take into account the good (or bad) faith of the obligor (or obligee) and any circumstances that might render enforcement of the penalty contrary to good faith. Furthermore, its nebulous character ensures the broad-

131 The first provision of Ch III which deals with Les Effets Des Obligations.

132 Zimmermann and Whittaker Good Faith in European Contract Law (Cambridge Cambridge University Press, 2000) 33.

133 Though it was not until 1985 that the Cour de cassation ruled on an appeal that was based on this provision-Civ 1, 20 mars 1985, B 1985 1, no 102.

134 'La concept de bonne foi en droit français du contrat' <http;//www.cnr.it/ CRDS/tallon.htm>. In several civilian systems the concept of good faith has developed far beyond what the common lawyer might immediately think of-Beale, 'Legislative Control of Fairness; The Directive on Unfair terms in Consumer Contracts' in Beatson and Friedmann (eds) Good Faith in Contract Law (Oxford Oxford University Press 1995).

135 La bonne foi est le moyen de faire pénétrer la règle morale dans le droit positif. Terré et al, above $\mathrm{n} 45$, at 347 .

136 Picod, above n 123

137 J Ghestin, Traité de Droit Civil-Les Obligations. Le Contrat: Formation (LGDJ 1988), at 184 sees loyalty as a necessary complement to contractual justice.

138 Flour and Aubert Les Obligations; L'Acte juridique (Paris Armand Colin 1998), at 386.

139 Harris and Tallon, above, n 116, at 386. 
est latitude of interpretation. In this way the competing legal objectives mentioned throughout this essay-certainty, individual justice and freedom of contract - can be evaluated in the light of all circumstances, from the conclusion of the contract to the moment of judgment.

The traditional English law focus on certainty, primordial in a system founded on commercial considerations and the consequential respect for the parties' agreement, has meant that it not only eschews the flexibility inherent in judicial revision of the clause but has been resistant to subjective, intrinsically indeterminate principles of good faith. ${ }^{140}$ Although concerned with repression and contractual justice, absence of legal recognition of a general principle of good faith ${ }^{141}$ has obfuscated open debate on such things as the behaviour of the parties or notions of morality in enforcing the clause according to the particular circumstances prevailing at the time. The subtle balancing act between justice, certainty and the freedom of contract that the courts openly perform in France through the interface of good faith, although present, is disguised by the awkward distinction between penalty and liquidated damages clauses. The 'balancing' is pre-formulated in the Dunlop guidelines that protect the individual through sweeping rejection of all penal elements to the clause. Since there is no 'safety-net' of subjective values to which the court can resort if, because of the imposition of a penalty, a party is unfairly penalised, ${ }^{142}$ any penal element is in principle excluded. The pitfalls of such an inflexible rule have been exposed in the inconsistencies already discussed - normative rigidity necessitates palliation through judicial interpretation and the admittance of a penalty through the 'back door'. Thus, in practice, classification of the clause as a penalty is influenced by the parties' bargaining positions, and often the extent to which the court feels it reasonable to rewrite the contract. The real policy decisions are however hidden behind a veil of judicial reasoning.

A noteworthy suggestion for a rationalisation of the common law comes from Waddams in his proposal for open recognition of the doctrine of unconscionability which he believes would rectify the inconsistencies that 'bedevil the law of penalty clauses'143 and promote justice in individual cases. Waddams aims to demonstrate how the court takes unconscionability into account much more than orthodox theory admits when it is classifying the

\footnotetext{
140 Whilst the prolific and protean nature of English commentary on good faith counsels against cursory mention of the principle, a deep examination is outside the true scope of this paper. See instead, eg, Beatson and Friedman (eds), above n 171; Bridge 'Does Anglo-Canadian Contract Law Need a Doctrine of Good Faith?' 9 Canadian Business Law Journal (1984) 385; Teubner 'Legal Irritants: Good Faith in British Law of How Unifying Law Ends up in New Divergences' 61 [1988] MLR 11: Zimmermann and Whittaker, above n 132; Brownsword et al 'Good Faith in Contract: Concept and Context' in Brownsword et al (eds) Good Faith in Contract: Concept and Context (Dartmouth Ashgate 1999).

141 'English law has . . . committed itself to no such overriding principle but has developed piecemeal solutions in response to demonstrated problems of unfairness' as per Lord Bingham, Interfoto Picture Library Ltd v Stiletto Visual Programmes Ltd [1989] QB 433, at 439.

142 Although note comments regarding Law Commission Report No 166 in Section V below.

143 Waddams The Law of Contracts (Toronto Canada Law Book Inc 1998), at 458.
} 
clause as a liquidated damages clause or a penalty clause. He claims that, even when the present rules were being expounded in Dunlop, the hidden core of the reasoning was whether the clause was an 'unreasonable' ${ }^{144}$ one or not. ${ }^{145}$ He believes that, rather than shackling legal development to a distinction between liquidated damages and penalty clauses, unconscionability should be explicitly recognised within solid legal theory. 'Clarity, justice and in the long run certainty' 146 would be best served if the courts could develop rational guidelines to aid future decisions.

The proposal is meritorious in the extent that focus would move towards concern with the substantive content of the clause. Reasonable terms would not be struck down or unreasonable ones upheld in blind application of mechanical rules. It would introduce explicit recognition of subjective values into the penalty clause rules, aligning what the law says with what it does. Furthermore a clause would not differ in treatment according to whether it operated on breach or not, thus resolving the 'absurd paradox'147 that presently exists. Instead, focus would be on whether enforcement would be unconscionable or not having regard to all the circumstances at the time the contract was concluded.

But the belief in the panacean qualities of unconscionability should be approached with care. The focus would not necessarily yield a more consistent and rational result. Like the French notion of bonne foi, unconscionability is a loose concept. Precise definition of the term itself has proved elusive, ${ }^{148}$ forewarning of inconsistencies and incoherence in its practical application-inimical to the business community to which the English legal system is harnessed. One must also seriously reflect on the effect of wholesale adoption of such a doctrine ${ }^{149}$ on other areas of the law, particularly in the light of the multifarious backdrops to a contractual relationship.

144 Waddams seems to equate 'unconscionability' with 'reasonableness'. See also Downes, above $\mathrm{n} 35$.

145 He draws support for his argument from the law lords' speeches, Lord Atkinson and Lord Dunedin both using the words 'unconscionable' to describe the clause under consideration and Lord Atkinson supplementing 'unconscionable' with 'unreasonable' and 'extravagant'. He further notes that in the facts of the case the clause, stipulating for a payment of $£ 5$ on each breach of the agreement, could hardly be described as a genuine pre-estimate of damage and that the only reason that it was enforced was that it was 'unreasonable'.

146 Waddams, above n 143, at 456.

147 United Dominion Trust (Commercial) Ltd v Ellis [1968] 1 QB 54, at 67.

148 The voluminous literature on the term proves its will-o-the-wisp nature. For example, the concept has been separated into substantive and procedural unconscionability-(Leff, 'Unconscionability and the Code-The Emperor's New Clause' 115 (1966-7) University of Pennsylvania 485), defined as 'substantive fairness'-(Smith 'In Defence of Substantive Fairness' 112 LQR (1996) 392) and as incorporating concepts such as unfairness, inequity, unreasonableness or oppression-Waddams above, n 143, at 543. One American commentator finds substantive unconscionability coterminous with the civilian idea of 'manifestly excessive' while procedural unconscionability draws on similar factors as are taken into account in the civilian review of the clause, Dimatteo, above n 113, at 653 .

149 Waddams does not limit unconscionability to penalty clauses but includes areas of contract such as interpretation, duress, and incorporation of documents. 
These arguments have a familiar resonance for the English lawyer. Similar concerns have been voiced in response to the mention of good faith. The relationship between unconscionability and the neighbouring principle of good faith is ambiguous. ${ }^{150}$ But the 'good faith debate' has taken on new relevance for the rules on penalty clauses in the light of the European Directive on Unfair Terms in Consumer Contracts ${ }^{151}$ and the subsequent 'transplant' 152 of the notion into English law. Already the French implementing legislation has threatened to eddy the calm waters of established doctrine in France and may prove to be the navigator for the new voyage that the penalty clause rules will embark upon in England.

\section{THE EC DIRECTIVE ON UNFAIR TERMS IN CONSUMER CONTRACTS}

The Directive applies to contract terms which have not been individually negotiated (Article 3) in contracts between consumers and sellers or suppliers. The purpose of the Directive is to regulate terms that are 'unfair' - where a term is deemed 'unfair' it will not be binding on the consumer (Article 6). A term would be considered unfair if "contrary to the requirement of good faith, it causes a significant imbalance in the parties' rights and obligations arising under the contract, to the detriment of the consumer' (Article 3(1)). An indicative and non-exhaustive list of the terms which may be regarded as unfair is included in an annex. Article 1 (e) of this annex includes a term 'requiring any consumer who fails to fulfil his obligation to pay a disproportionately high sum in compensation' - a term that can be recognized as a penalty clause.

Implementation of the Directive in England was through an almost verbatim text in the form of The Unfair Terms in Consumer Contracts Regulations 1999. The inclusion of good faith in section 5 (1) is not without controversy. Its insertion has been seen as either superfluous, as 'mysterious and exciting, 153 and as a complementary, not autonomous, criterion. It does not have to be added to the requirement of 'significant imbalance' and neither does the significant imbalance have to be caused by a lack of good faith. ${ }^{154}$ For some

\footnotetext{
${ }^{150}$ Good faith has been likened to the 'surprise' factor in a contract and unconscionability the 'imbalance'; Dugan 'Standardized Forms; Unconscionability and Good Faith' 14 New England Law Review (1979) 711. Despite the fact that both 'sound somewhat familiar' good faith has different meanings in different contexts whereas unconscionability can encompass and unify quite different legal techniques under the same doctrinal umbrella. It is this difference that excludes good faith from similar treatment to unconscionability - Waddams 'Good Faith, Unconscionability and Reasonable Expectations' 9 JCL (1995), at 57-9. (Waddams, curiously, is very much against adoption of good faith as a general principle). Steyn 'Contract Law; Fulfilling the Reasonable Expectations of Honest Men' 113 LQR [1997] 433 likens good faith to 'reasonable expectations'. Collins 'Good Faith in European Contract Law' 14 Oxford Journal Legal Studies (1994) 229, at 250 perceives unconscionability in similar terms as the French notion of bonne foi.

151 93/13/EEC. $\quad 152$ Teubner, above n $140 . \quad 153$ Collins, above n 150, at 249

154 Tenreiro 'The Community Directive on Unfair Terms and National Legal Systems. The Principle of Good Faith and Remedies for Unfair Terms' European Review of Private Law (1995) 273 at 279 and Beale above $n 134$ at 245.
} 
good faith is seen in civil law terms. Collins, for example, sees it as 'a deeper form of contractual solidarity'. ${ }^{155}$ If good faith is to be interpreted by the court in the area of consumer contracts in such a broad way then it is possible that the notion will infiltrate other areas of contracts. ${ }^{156}$ It is unlikely that strict delineation between a penalty clause in a consumer contract and one in a commercial contract would survive. It is more plausible that considerations of fairness and good faith would affect interpretation of the latter. This seems all the more likely in the light of a recent Law Commission Consultation paper No 166 which considers fusing the Regulations and UCTA 1977 into a single unified regime and extending the scope of the legislation to cover the type of unfair term in a 'business-to-business' contract which are currently outside the ambit of UCTA but which, (had they been in a consumer contract) would fall within the Regulations. The notion of good faith would then take on new importance in such an expanded area. It is not improbable that the focus of judicial discretion will shift from the classification of the clause to perceptions of substantive fairness and good faith. If this is indeed the case, the argument for reforming the Dunlop criteria and rejecting the distinction between liquidated damages and penalty clauses would be strengthened. This variation in discretionary power would have the advantage of circumventing misleading judicial reasoning based on the supposed intentions of the parties in situations where the penalty has been fairly negotiated between parties of equal commercial strength and clearly forms part of the contract price. The clause can be enforced where it is not considered unfair. However, it would also meet the objections voiced above regarding unconscionability and its potential for inconsistency and subsequent uncertainty.

The impact of the Directive on the French clause pénale is no less far reaching. Terms are considered as 'abusives' where their aim or effect is to 'créer, au détriment du non-professionnel ou du consommateur, un déséquilibre significatif entre les droits et obligations des parties au contrat'. ${ }^{157}$ As seen, French law is no stranger to good faith but, interestingly, it was omitted from the 1995 implementing law. ${ }^{158}$ Two presumptions can be attributed to this omission; first, inclusion of bonne foi is unnecessary since it already forms part of the general principles of French law; secondly, a term drafted by a professional in a contract with a consumer which caused a 'significant imbalance' would automatically be contrary to good faith since it would be a clear abuse of his economic superiority. Inclusion therefore is considered otiose.

The Directive has important implications for the French rules on clause

155 Collins, above n 150 , at 250.

156 This is considered to be the case in France; in consumer law 'les règles ont de surcrôit tendanace à s'étendre par contagion à d'autres secteurs' Chabas, above n 67 at 634.

157 Article L 132-1.

158 Loi no. 95-96 du 1er févr 1995. The report from the Commission on the implementation of Council Directive 93/13/EEC of 5 Apr 1993 on unfair terms in consumer contracts (COM/2000/248 final) considers that France has incorrectly implemented this article. 
pénales where these are drafted into a contract between, on the one hand, a professional, and on the other, a consumer. ${ }^{159}$

As mentioned, a clause that is deemed to be unfair is considered as nonbinding on the consumer. ${ }^{160}$ But as mentioned above, provision 1(e) of the Annexe, literally transposed into the French law, includes as indicative a term that imposes on a consumer in breach of his obligation a 'disproportionately high sum' in compensation - the recognizable clause pénale. There is an obvious correlation between a clause abusive stipulating a 'montant disproportionnellement élevé and a clause pénale that stipulates for a sum that is 'manifestement excessive'. But the two regimes conflict. Where a clause is classified as 'pénale', it will be subject to judicial powers of revision under Article 1152 al 2. Where it is deemed abusive, it will be non-binding, and the consumer, or non-professional, is rescued from the vagaries of judicial discretion. There is clearly an incompatibilité des sanctions. ${ }^{161}$ Furthermore, the moment of the judge's evaluation differs. As seen above, the amount of the clause pénale is assessed at the time of the judgment, but the abusive nature of the clause abusive is evaluated at the time the contract was concluded. The repercussions for the judicial role is that in the domain of consumer contracts the classification of a clause becomes ever more crucial. The potential for inconsistencies and incoherence may increase as the focus of litigation is directed towards attempts at bringing the contract within the protection of consumer law.

It should be noted that, in many situations disparities will be mitigated. Even where a clause falls within consumer law and is considered non-binding, this does not mean that the obligor is released from liability. He will be subject to the rules on damages as evaluated by the courts. Where the clause is outside consumer law, the judge has the discretion to modify it to an amount just above actual loss. ${ }^{162}$ The difference, in practical terms, between the two sums may therefore prove nominal. ${ }^{163}$ But, importantly, the practical position of the obligor remains wholly contingent on the discretionary power of the judge. The classification of the clause, the decision to modify and then the amount by which to reduce it - all remain a judicial prerogative capable of varying interpretation. Unless the powers are exercised with an eye to compatibility between both areas, divergence between consumer law and general contract principles is conceivable.

These uncharted waters through which the penalty clause rules are journeying represent the next stage of evolution, for which the European Community

159 Or a 'non-professional' according to the French transposing legislation.

160 Les clauses abusives sont réputées non écrites Art L132-1 al 6.

161 D 1992 Somm. 268 obs Kullmann. Also, see Paisant, above n 61 '[L]e legislateur n'avait pas songé aux clauses pénales en modifiant la definition des clause abusives'.

162 Or according to some commentators, to an amount that equals loss. See above.

163 One could argue that the consumer would be adequately protected under Art 1152 Code civil without resort to the Code de la consommation. This is mooted by Kullmann, above 161. But since the 1993 law is a lex specialis it is to this that one should resort; Starck et al. above n 45, at 1833. 
is serving as compass. Whilst it is Member States' particular contractual traditions, commercial priorities and cultural preferences which have shaped the present rules, modern global networks of trade and commerce that render uniformity commercially expedient may well prove irresistible. ${ }^{164}$ The precise nature and form that any European harmonization of contract law will take remains, of course, unsettled, ${ }^{165}$ but, outside the consumer area, joint Member State work on the Principles of European Contract Law, as well as international projects such as the Unidroit principles of commercial contract, have been successfully realised. Although non-binding, they reveal a preference for the recognition of a penalty accompanied by a modification power that can reduce the sum where it is grossly excessive in relation to the loss. ${ }^{166}$ The civilian influence on these general principles and the divergence from English rules is evident. Although some commentators have likewise seen the EC Directive as drafted from an almost entirely civilian perspective, ${ }^{167}$ within the realm of the penalty clause, it has been seen that EC consumer protection concerns have nevertheless brought distortion to civilian rules. The disruptive effect of EC action thus proves impartial. One can only hope that any future EC action will be wary of contributing further to the incoherence hitherto prevalent in the penalty clause rules.

164 Even for the United Kingdom, whose commercial legal roots are attractive to foreign investment and who stands to gain the most from resisting harmonisation.

165 Consultation and discussion continues at the European Community level. See the recent Communication from the Commission to the European Parliament and the Council of 12 Feb 2003 (COM (2003) 68 final). This 'Action Plan' continues the consultative nature of the process begun by the Commission Communication of 11 July 2001 (COM (2001) 398 final).

166 Art 9:509 PECL; Art 7.4.13. Unidroit.

167 A de Moor, above n 121, at 262. 